УДК 343.4

DOI https://doi.org/10.32837/pyuv.v0i1.739

\author{
О. В. Ільӥна \\ orcid.org/0000-0003-4848-3120 \\ кандидат юридичних наук, доцент, \\ доцент кафедри кримінально-правової політики та кримінального права \\ Інституту права \\ Київського національного університету імені Тараса Шевченка
}

\title{
ДО ПИТАННЯ ПРО ЕФЕКТИВНІСТЬ КРИМІНАЛЬНО-ПРАВОВОЇ ПРОТИДІЇ БУЛІНГУ В ЧИННОМУ КРИМІНАЛЬНОМУ ЗАКОНОДАВСТВІ
}

Конституція України проголосила людину, iï життя і здоров'я, честь і гідність, недоторканність і безпеку найвищою соціальною цінністю. Права і свободи людини та їх гарантії визначають зміст і спрямованість діяльності держави. Держава відповідає перед людиною за свою діяльність. Утвердження і забезпечення прав і свобод людини є головним обов'язком держави (ст. 3) [1]. Оскільки Конституція України має свою силу на всій території України та стосується всіх її громадян, можна з упевненістю сказати, що людина як найвища соціальна цінність має захищатися у всіх сферах iï життя: побутовому, соціальному, правовому. Що стосується соціального життя людини та її комунікацій 3 іншими особами, вважаємо за необхідне згадати ст. 28 Основного Закону: «Кожен має право на повагу до його гідності. Ніхто не може бути підданий катуванню, жорстокому, нелюдському або такому, що принижує його гідність, поводженню чи покаранню» [1]. Цитована стаття набуває особливого значення в сучасних умовах підвищення рівня підліткової агресії. Вчені наводять статистику, що «за даними Всесвітньої організації охорони здоров’я, Україна посідає четверте місце у світі за рівнем підліткової агресії, поступаючись лише Росії, Албанії та Білорусі» [2, с. 107]. Ці шокуючі дані свідчать про масштабність піднятого питання та актуальність вибраної теми дослідження.

Проблема булінгу є досить поширеною у світі. Не тільки Україна занепокоєна цим питанням, але і США, Велика Британія, Франція, Італія, Канада, Швеція тощо. Тому «булінг» став предметом дослідження серед учених усього світу, таких як О. Лавриненко, Д. Лейн, Д. Олвеус, В. Панок, П. Рендолл, В. Синьов та інші.

Водночас варто зауважити, що явище булінгу досліджується з різних аспектів: соціального, педагогічного, правового, в тому числі з погляду кримінального та адміністративного права. 3 огляду на багатоаспектність цього явища, вважаємо за необхідне звузити сферу дослідження до аналізу соціального та правового аспектів, оскільки вони нерозривно пов'язані між собою та потребують комплексного дослідження.
Звертаючись до тлумачення терміна «булінг», учені визначають, що він означає «цькування, залякування, агресивне переслідування одного із членів колективу з боку інших представників колективу» [2, с. 108]. «Булінг може проявлятись у вигляді психологічного тиску (образи, приниження, погрози, ігнорування тощо) та фізичних знущань (удари, поштовхи, принизливий фізичний контакт, побиття та інше). Нерідко фізичний і психологічний тиск об'єднуються» [3]. Продовжуючи дослідження, варто зауважити, що термін «булінг» віднедавна став не тільки науковим або соціальним терміном, але і законодавчим.

Якщо спроектувати зроблені висновки у площину Кримінального кодексу України, то слід звернути увагу на такий склад кримінального правопорушення, як катування: «Катування, тобто умисне заподіяння сильного фізичного болю або фізичного чи морального страждання шляхом нанесення побоїв, мучення або інших насильницьких дій із метою примусити потерпілого чи іншу особу вчинити дії, що суперечать їхній волі, у тому числі отримати від нього або іншої особи відомості чи визнання, або з метою покарати його чи іншу особу за дії, скоєні ним або іншою особою чи у скоєнні яких він або інша особа підозрюється, а також з метою залякування чи дискримінації його або інших осіб» (ч. 1 ст. 127) [4]. Визначальною ознакою, яка є дуже схожою із характеристикою булінгу, на наш погляд, є заподіяння морального страждання шляхом насильницьких дій. Зрозуміло, що насильницькі дії можуть бути різного характеру, і не обов'язково це має бути фізичний вплив на особу. Фактично ми ведемо мову про те, що окремі прояви булінгу підпадають під визначення катування.

Окрім цього, як уже зазначалося, наслідком булінгу іноді стає самогубство, у зв'язку з чим слід звернути увагу на ч. 1 ст. 120 Кримінального кодексу України «доведення до самогубства: доведення особи до самогубства або до замаху на самогубство, що є наслідком жорстокого 3 нею поводження, шантажу, систематичного приниження їі людської гідності або систематичного протиправного примусу до дій, що суперечать 
іï волі, схиляння до самогубства, а також інших дій, що сприяють вчиненню самогубства» [4]. У цьому складі кримінального правопорушення наслідком булінгу може бути шантаж, систематичне приниження людської гідності. Фактично в цьому складі кримінального правопорушення може йтися про булінг, який став причиною вчинення самогубства.

Як зазначають учені, «таке кримінальне правопорушення, як шантаж, також доцільно відносити до психологічних катувань, адже він реалізується шляхом погрози, умовою невтілення в життя якої є вдавання потерпілого до певного вчинку» [2, с. 108]. Однак варто пояснити, що такий склад кримінального правопорушення, як «шантаж», відсутній у сучасному Кримінальному кодексі України. Цей термін міститься в інших складах кримінального правопорушення, зокрема у ст. 120 «доведення до самогубства», ст. 149 «торгівля людьми», ст. 258-1 «втягнення у вчинення терористичного акту», ст. 303 «сутенерство або втягнення особи в заняття проституцією» [4].

Також вважаємо за доцільне звернути увагу на такий склад кримінального правопорушення, як «хуліганство, тобто грубе порушення громадського порядку з мотивів явної неповаги до суспільства, що супроводжується особливою зухвалістю чи винятковим цинізмом» [4]. Як свідчить практика, булінг досить часто кваліфікується саме за цим складом кримінального правопорушення.

Не можна залишити поза увагою склад кримінального правопорушення, передбачений ст. 166 Кримінального кодексу України «злісне невиконання обов' язків по догляду за дитиною або за особою, щодо якої встановлена опіка чи піклування». Фактично у цьому складі кримінального правопорушення йдеться про відповідальність батьків за вчинення їх дітьми протиправних дій, зокрема булінгу.

Щодо суб’єктного складу названих кримінальних правопорушень, слід звернути увагу на те, що «булінг» визначається як протиправна діяльність дітей шкільного віку. Водночас відповідальність за кримінальне правопорушення у формі катування несуть особи у віці від 16 років. За ст. 120 "доведення до самогубства» відповідальність настає також лише з 16 років. I лише за вчинення хуліганства відповідальність настає з 14 років. Такий висновок грунтується на аналізі ст. 22 Кримінального кодексу України «вік, з якого може наставати кримінальна відповідальність", за якою за загальним правилом «кримінальній відповідальності підлягають особи, яким до вчинення кримінального правопорушення виповнилося шістнадцять років» і лише у виключному переліку випадків передбачена відповідальність з 14 до 16 років [4]. Тобто склалася проблемна ситуація: 3 одного боку, булінг - це проблема саме школярів; з іншого - кримінальна відповідальність за вчинення дій, що фактично становлять собою булінг, настає здебільшого з 16 років, коли школярі переважно закінчують школу. Вважаємо, що проілюстрована ситуація має якнайшвидше вирішитися на законодавчому рівні. На наш погляд, рішенням може бути закріплення в Кримінальному кодексі України складу кримінального правопорушення «булінг», який буде відрізнятися за тяжкістю наслідків від аналогічного адміністративного складу правопорушення.

3 метою додаткового обгрунтування запропонованих змін пропонуємо звернутися до правозастосовної практики. Фактично вона має надати відповідь на запитання: «Чи є булінг кримінальним правопорушенням?» Детальний аналіз рішень, які були винесені судами України, свідчить про те, що судді нині все частіше визнають булінг саме кримінальним правопорушенням, а не адміністративним правопорушенням. Так, у справі № 330/471/19 «заявниця звернулася до суду зі скаргою на прийняте рішення начальником Якимівського ВП Мелітопольського ВП ГУНПУ в Запорізькій області від 06 березня 2019 р. за їі заявою про злочин, вчинений учителем Якимівської ЗОШ № 2 ОСОБА_2. Раніше вона звернулась із заявою про злочин до Мелітопольської місцевої прокуратури, де зазначила, що вчитель ОСОБА_2 вчинює протиправні дії щодо її сина ОСОБА_3, який навчається в 2-б класі. Так, під час освітнього процесу знущалася над їі сином, принижувала його, застосовувала психологічне насилля. Здійснювала цькування малолітнього сина з боку батьків та дітей класу. У заяві заявниця просила скасувати рішення начальника Якимівського ВП Мелітопольського ВП ГУНПУ в Запорізькій області від 06 березня 2019 р. та внести відомості до ЄРДР щодо вчителя ОСОБА_2 за їі заявою про злочин від 25 лютого 2019 р. Прокурор С.Г. Шульженко заперечував проти вказаної скарги та вказав, що заявник фактично вказує на наявність із боку вчителя булінгу щодо сина заявниці. За вказані дії передбачена адміністративна відповідальність, а тому немає підстав для внесення заяви до ЄРДР». Однак слідчий суддя вирішив, що «скарга ОСОБА_1 є обгрунтованою та підлягає задоволенню, і зобов' язав скаргу заявниці на бездіяльність прокурора та слідчого щодо невнесення відомостей до Єдиного реєстру досудових розслідувань за її заявою від 25 лютого 2019 року щодо вчителя Якимівської ЗОШ № 2 ОСОБА_2 - задовольнити; зобов'язати прокурора Якимівського відділу Мелітопольської місцевої прокуратури внести до Єдиного реєстру досудових розслідувань заяву ОСОБА_1 від 25 лютого 2019 року про злочин, вчинений учителем Якимівської ЗОШ № 2 ОСОБА_2 [5]. Фактично суд констатує той факт, що булінг в окремих його проявах є складом 
кримінального правопорушення та потребує внесення відомостей до Єдиного реєстру досудових розслідувань і вчинення подальших дій відповідно до Кримінального процесуального кодексу України.

Аналогічна ситуація склалася і у м. Ірпінь Київської області. Так, «до суду зі скаргою звернувся ОСОБА_1 на бездіяльність слідчого, яка полягає у невнесенні відомостей про кримінальне правопорушення до Єдиного реєстру досудових розслідувань із тих підстав, що 16.05.2018 p. ним було подано заяву про вчинення дій, що містять ознаки злочину, до Ірпінського ВП ГУ НП України в Київській області, що підтверджується наданим у заяві номером EO 9800 від 16.05.2018 р. У поданій заяві йшлося про факти «шкільного булінгу». Після подачі заяви про вчинення кримінального правопорушення жодних дій, спрямованих на внесення наданих відомостей до Єдиного реєстру досудових розслідувань та здійснення досудового слідства органом досудового розслідування, не вчинялося». Далі заявник зазначає, що «станом натепер відомості до Єдиного реєстру досудових розслідувань за заявою про вчинення дій, що містять ознаки злочину, не внесені, і просить зобов'язати слідчих Ірпінського ВП ГУ НП України в Київській області невідкладно зареєструвати подану заяву про вчинення злочину до Єдиного реєстру досудових розслідувань та розпочати за цією заявою про вчинення злочину досудове розслідування у формі досудового слідства за вчення дій, які мають ознаки складів злочину, передбачені ч. 2 ст. 127, ч. 2 ст. 146, ч. 2 ст. 296 КК України». У свою чергу представник суб'єкта оскарження Ірпінського ВП ГУ НП в Київській області в судове засідання не з'явився, про час та місце розгляду справи був належним чином повідомлений. Суд, вислухавши скаржника, дослідивши матеріали скарги, вважає її такою, що підлягає до задоволення, виходячи із таких підстав. На підставі вищенаведеного, керуючись статтями 214, 303, 304 КПК України, суд вирішив скаргу задовольнити та зобов'язати слідчих Ірпінського ВП ГУ НП України в Київській області невідкладно зареєструвати подану ОСОБА_1 заяву про вчинення злочину до Єдиного реєстру досудових розслідувань та розпочати за цією заявою про вчинення злочину досудове розслідування у формі досудового слідства за вчення дій, які мають ознаки складів злочину, передбачені нормами КК України [6]. Як ми бачимо, судді визнають булінг кримінальним правопорушенням і зобов' язують слідчі органи діяти відповідно до норм кримінального процесуального законодавства, а не адміністративного.

Ще одним свідченням того, що правозастосовна практика визнає булінг кримінальним правопорушенням, є Ухвала Шосткинського міськрайонного суду Сумської області, де серед інших обстави справи зазначено, що «22.02.2019 року ОСОБА_10 в присутності понятих добровільно видала в якості речового доказу мобільний телефон, а саме: марки «ZTE», модель «V9», IMEI: 1) HOMEP_1, 2) HOMEP_2, який вона 21.02.2019 у добровїльному порядку вилучила у ОСОБА_8 під час проведення розслідування випадку булінгу». Тобто йдеться про те, що у рішеннях по кримінальних справах вживається термін «булінг» [7]. Фактично булінг уже розслідується як кримінальне правопорушення, і подальші дії залишаються саме за законодавцем.

Проведене дослідження свідчить, що булінг це явище, яке вже давно перестало бути суто адміністративно-правовим, і нині воно підпадає під кримінально-правові характеристики через те, що його наслідками часто стають наслідки кримінального характеру. Детальний аналіз норм Кримінального кодексу України дає можливість зробити висновок, що окремі прояви булінгу знайшли своє відображення у таких складах кримінальних правопорушень, як катування, доведення до самогубства, хуліганство. Приклади правозастосовної практики свідчать про те, що судді все частіше визнають булінг кримінальним правопорушенням, упереджуючи в цьому законодавця. 3 урахуванням наведеного пропонується закріпити в Кримінальному кодексі України склад кримінального правопорушення «булінг». Така пропозиція відповідає вимогам часу та сприятиме захисту прав потерпілих від шкільного цькування.

\section{Jimepamypa}

1. Конституція України. Офіційний вісник України. 2010. № 72/1. С. 15. Ст. 2598.

2. Соціальна та кримінально-правова характеристика булінгу. Науковий вісник Херсонського державного університету. 2018. Вип. 3. Том 2. С. 107-110.

3. Що таке «булінг» та чому про нього треба знати всім батькам: пояснюють у центрі соціальних служб. URL: https://bilyayivka.city/read/card/3080/ scho-take-buling-ta-chomu-pro-nogo-treba-znati-vsimbatkam-poyasnyuyut-u-centri-socialnih-sluzhb (дата звернення: 28.07.2019).

4. Кримінальний кодекс України: Кодекс України, Кодекс, Закон від 05.04.2001 № 2341-III. Відолості Верховної Ради України (ВВР ). 2001. № 25-26. Ст. 131.

5. Ухвала Якимівського районного суду Запорізької області від 15.03.2019 р., судова справа № 330/471/19. URL: http://reyestr.court.gov.ua/ Review/80467488 (дата звернення 29.07.2019).

6. Ухвала Ірпінського міського суду Київської області від 06 червня 2018 р., судова справа № $367 / 3688 / 18$. URL: http://reyestr.court.gov.ua/ Review/74525084 (дата звернення 29.07.2019).

7. Ухвала Шосткинського міськрайонного суду Сумської області від 27 лютого 2019 р., судова справа № 589/751/19. URL: http://reyestr.court.gov.ua/ Review/80493940 (дата звернення 29.07.2019). 


\section{Анотація}

Ільїна О. В. До питання про ефективність кримінально-правової протидії булінгу в чинному кримінальному законодавстві. - Стаття.

У статті досліджено соціальну та кримінально-правову характеристику такого явища, як «булінг». У результаті ускладнення ситуації в соціально-політичній, економічній, освітній та інших сферах суспільного життя рівень насильства в суспільстві нині збільшився в декілька разів. Підлітки є найбільш вразливою категорією суспільства. Оскілки саме в так званому перехідному віці активно формуються власна система сприйняття світу, система цінностей та пріоритетів, то діти переймають різні моделі поведінки дорослих, i, на жаль, насильство стає однією з таких моделей. Однією з найпоширеніших проблем у дитячому середовищі сьогодні є булінг, який прийнято розглядати як небажану агресивну поведінку дітей шкільного віку, що призводить до цькування дитини іншою дитиною або групою дітей з метою приниження, залякування та демонстрації сили. Проведене дослідження свідчить, що булінг - це явище, яке вже давно перестало бути суто адміністративно-правовим, і нині воно підпадає під кримінально-правові характеристики через те, що його наслідками часто стають тілесні ушкодження, моральні страждання, тобто наслідки, які містяться у складах кримінальних правопорушень. На жаль, «деякі жерти знущань настільки страждають, що закінчують або намагаються покінчити 3 життям самогубством. Буліцид - поняття, яке означає вчинення самогубства жертвами знущань у школі 3 метою припинення страждань. Детальний аналіз норм Кримінального кодексу України дає можливість зробити висновок, що окремі прояви булінгу знайшли своє відображення у таких складах кримінальних правопорушень, як катування, доведення до самогубства, хуліганство. Приклади правозастосовної практики свідчать про те, що судді все частіше визнають булінг кримінальним правопорушенням, упереджуючи в цьому законодавця. 3 урахуванням наведеного пропонується закріпити в Кримінальному кодексі України склад кримінального правопорушення «булінг». Така пропозиція відповідає вимогам часу та сприятиме захисту прав потерпілих від шкільного цькування.

Ключові слова: булінг, цькування, приниження, катування, самогубство, хуліганство, потерпілий.

\section{Summary}

Ilina $O . V$. To the question about efficiency of criminal law counteraction to bullying in the current criminal law. - Article.

The research paper deals with the social and criminal law characteristics of such phenomenon as "bullying". The conducted research shows that bullying is a phenomenon that is no longer purely administrative and legal, and is now subject to criminal law characteristics because it often entails criminal consequences. A detailed analysis of the provisions of the Criminal Code of Ukraine allows concluding that certain manifestations of bullying were reflected in corpus delicti as torture, driving to suicide, hooliganism. With respect to the subjective nature of these criminal offenses, it should be noted that "bullying" is defined as the unlawful activity of school-age children. At the same time, persons over the age of 16 are responsible for the criminal offense in the form of a torture. Under Article 120 "Driving to Suicide, responsibility is born only by persons aged above 16. And only for hooliganism responsibility is born by persons aged above 14. That is, now we have a situation where, on the one hand, bullying is a problem for pupils, and on the other, criminal responsibility for committing actions that actually constitute bullying is born in most cases from the age of 16 , when the pupils mostly leave school. We believe that the illustrated situation should be resolved at the legislative level as soon as possible. Examples of law enforcement practice indicate that judges increasingly recognize bullying as a criminal offense, prejudging the legislator. The research paper describes the judgements of the Ukrainian courts that oblige law enforcement agencies to enter information about the facts of bullying to the Unified Register of Pre-trial Investigations. In view of the above, it is proposed to enshrine corpus delicti of "bullying" in the Criminal Code of Ukraine. Such a proposal meets the requirements of the present time and will help protect the rights of victims of school bullying. The fact that corpus delicti of the criminal offense will be different from corpus delicti of the administrative offense enshrined in Article 173-4 of the Code of Ukraine on Administrative Offenses "Bullying (Harassment) of a Participant in the Educational Process".

Key words: bullying, harassment, humiliation, torture, suicide, hooliganism, victim. 